\title{
Activity of Culicoides spp. (Diptera: Ceratopogonidae) inside and outside of livestock stables in late winter and spring
}

\author{
Daniela Kameke $^{1} \cdot$ Helge Kampen ${ }^{2} \cdot$ Doreen Walther $^{1}$
}

Received: 10 November 2016/Accepted: 20 December 2016 /Published online: 4 January 2017

(C) The Author(s) 2017. This article is published with open access at Springerlink.com

\begin{abstract}
Culicoides Latreille, 1809 midge species are the putative vectors of Bluetongue virus (BTV) and Schmallenberg virus (SBV) in Europe. To gain a better understanding of the epidemiology of the diseases, basic knowledge about the overwintering of the vectors is needed. Therefore, we investigated culicoid activity in relation to air temperature at livestock stables during late winter and spring season. Ceratopogonids were captured weekly indoors and outdoors on three cattle farms, three horse farms and one sheep farm in the federal state of Brandenburg, Germany between January and May, 2015 by BG-Sentinel UV-light suction traps. First seasonal activity was measured inside a sheep barn and cattle stables in mid-March, suggesting the existence of a preceding vector-free period. The first species at all trapping sites were members of the Obsoletus Complex followed by Culicoides punctatus (Meigen), 1804 and Culicoides pulicaris (Linnaeus), 1758 simultaneously. In total, 160 collections were made, including 3465 Culicoides specimens with 2790 $(80.6 \%)$ of them being members of the Obsoletus Complex. The remaining 675 individuals belonged to six other culicoid species. 59.8\% of all Culicoides were collected indoors, and almost five times as many midges were sampled on cattle farms as on horse farms. Cattle farms harboured seven species while only two species were found on the horse and the sheep farms, respectively. Temperatures, husbandry practises and
\end{abstract}

Daniela Kameke

daniela.kameke@zalf.de

1 Institute of Land Use Systems, Leibniz Centre for Agricultural Landscape Research (ZALF), Eberswalder Str. 84, 15374 Müncheberg, Germany

2 Institute of Infectology, Friedrich-Loeffler-Institute (FLI), Südufer 10, 17493 Greifswald, Germany the presence/quality of potential breeding sites might be responsible for the difference in species and numbers of caught specimens between livestock holdings.

Keywords Overwintering $\cdot$ Biting midges $\cdot$ Farms $\cdot$ Winter phenology $\cdot$ Vectors $\cdot$ Arboviruses

\section{Introduction}

Since the outbreak of bluetongue disease in Central and northern Europe in 2006, the interest attracted by culicoid biting midges (Diptera: Ceratopogonidae) as virus vectors has increased significantly. These dipteran insects are known to transmit numerous pathogens, including Bluetongue virus (BTV) (genus Orbivirus, family Reoviridae) and Schmallenberg virus (genus Orthobunyavirus, family Bunyaviridae). Both viruses are known to be transmitted by several culicoid species such as members of the Obsoletus Complex (De Regge et al. 2012; Hoffmann et al. 2009; Mehlhorn et al. 2007; Rasmussen et al. 2012) and some species of the Pulicaris Group (Hoffmann et al. 2009; Larska et al. 2013).

After their first appearance in Central and northern Europe, both bluetongue and Schmallenberg disease re-emerged in consecutive years in several European countries (Conraths et al. 2013; Hoffmann et al. 2008), infecting ruminants and causing high losses to the farming industry. The recurrence of both diseases gave reason to suggest that their pathogens were able to survive the cold winter months (Doceul et al. 2013; EFSA 2012; Hoffmann et al. 2009). Up to this day, the exact mechanisms underlying the overwintering of BTV and Schmallenberg virus (SBV) in temperate zones have remained unclear, though (EFSA 2014; Napp et al. 2011). 
The persistence of the viruses within their adult biological vectors is considered by many to be the most likely pathway of overwintering (Doceul et al. 2013; Goffredo et al. 2013; Hoffmann et al. 2008; Larska et al. 2013; Losson et al. 2007; Mehlhorn et al. 2009a, b; Tarlinton et al. 2012).

Initially, most biting midge species of the genus Culicoides Latreille, 1809 had been believed to outlast the winter months as larvae (Mellor et al. 2000; Rawlings and Mellor 1994; Rowley 1967). Due to the recurrence of BTV, followed by acute SBV infections during winter (Wernike et al. 2013), it was soon speculated that a constant adult midge population might remain active throughout the coldest months of the year (Hoffmann et al. 2008; Losson et al. 2007; Tarlinton et al. 2012). Some studies soon confirmed permanent midge activity during winter even in temperate regions (Hoffmann et al. 2009; Mehlhorn et al. 2009a, b). Critical voices, however, do not believe that the low adult midge population during winter is able to keep the virus circulation alive until the start of the next vector season. Therefore they suggest, that other, so far undetected pathways, might exist which can explain the persistence of viruses (Napp et al. 2011).

The present study was conducted to provide baseline information on the winter phenology of biting midges near livestock animals. We aimed to determine the culicoid species composition inside and outside of different livestock stables during late winter and spring and try to identify (speciesspecific) temperatures which initiate midge activity.

\section{Materials and methods}

\section{Study period, area and sites}

Insect collections took place between 25 January and 10 May 2015 at three cattle stables and three horse stables. Additionally, one stable harbouring sheep was tested between mid-March and May, 2015. All stables were located in the German federal state of Brandenburg in two regions ca. $50 \mathrm{~km}$ apart from each other (Table 1) and sampled on an almost weekly basis.

All stables were of solid structure and shut for the most part, but contained permanent openings useable as entrances for flying insects. They harboured exclusively cattle, horses or sheep with $>5$ host animals being continuously kept inside the stables. More animals of the same species were present outside at all times, belonging either to the barnyard of examination or to neighbouring farms.

Dung heaps, potential breeding sites of some Obsoletus Complex species, existed on all cattle and horse farms within a 50-100 m radius to the outdoor traps. Stables were cleaned on a daily basis, except for the sheep stable and cattle stable 1 . The sheep stable was a deep-straw bedding stable, which was only cleaned after the end of the sampling period after 4 years
Table 1 Location and number of collections at all sampling sites

\begin{tabular}{llll}
\hline Farm & Coordinates & Site & No. of samples \\
\hline Region 1 & & & \\
Horse 1 & N 52.363679 & Inside & 10 \\
& E 13.391921 & Outside & 10 \\
Horse 2 & N 52.375751 & Inside & 13 \\
& E 13.367597 & Outside & 13 \\
Horse 3 & N 52.398795 & Inside & 10 \\
& E 13.447769 & Outside & 10 \\
Region 2 & & & \\
Cattle 1 & N 52.541143 & Inside & 14 \\
& E 14.18044 & Outside & 14 \\
Cattle 2 & N 52.541157 & Inside & 14 \\
& E 14.168886 & Outside & 14 \\
Cattle 3 & N 52.567115 & Inside & 11 \\
& E 14.231117 & Outside & 11 \\
Sheep & N 52.513221 & Inside & 8 \\
& E 14.17472 & Outside & 8 \\
\hline
\end{tabular}

of usage. Cattle stable 1 was a freestall and was cleaned once during the collection period in early February 2015.

Owing to only one sheep farm examined and the differing conditions between this farm and the other farms (no neighbouring farms close by, surrounded solely by fields, draughty location, no dung heaps and deep-straw bedding type), the results obtained from the sheep farm were considered "additional" and are therefore often discussed separately.

\section{Biting midge collection}

For the collection of biting midges, two BG-Sentinel UV-light traps (Biogents, Regensburg, Germany) were operated on every farm. One trap was installed inside each stable, the second outside, at approximately $2 \mathrm{~m}$ height with its trapping hole. Both traps were located in close distance to a permanent stable opening. At the same time, the inside traps were placed next to the potential hosts, the outside traps right at the stable building and also in close distance to the host animals $(<30 \mathrm{~m})$. All traps were run once a week for $24 \mathrm{~h}$, with both traps per farm being operated simultaneously. Sampling only took place when weather conditions were suitable for midge activity (no heavy rain or wind).

A Hobo Pro v2 data logger (Onset Computer Corporation, Bourne, MA, USA) was placed right beside each indoor insect trap (at the same height within approximately $30 \mathrm{~cm}$ ) to record the inside temperatures every $4 \mathrm{~h}$ during the entire sampling period. Outside temperatures were obtained from two permanent weather stations in $2 \mathrm{~m}$ height (region 1: Airport Berlin- 
Brandenburg N 52.38, E 13.52; region 2: Müncheberg N 52.52, E 14.12).

Insects were caught and stored in ethanol (75\%) until morphological identification to species or complex level under a stereomicroscope using the keys of Delécolle (1985) and Mathieu et al. (2012). Species represented by only a few individuals were further subjected to molecular analysis by COI barcoding using primers PanCuli-COX1-211F and PanCuliCOX1-727R, as described by Lehmann et al. (2012).

In the following analysis, the term "threshold temperature" marks the mean temperature of the 7 days prior to the first measured midge activity at a site or of a specific culicoid species. The mean weekly temperature instead refers to the average temperature of the named calendar week.

\section{Results}

Throughout the sampling period, 160 trap catches were made. A total of 3667 ceratopogonids were collected of which 3465 (94.5\%) belonged to the genus Culicoides. 3372 of the culicoid midges were females $(97.3 \%)$, and $80.5 \%$ $(n=2790)$ were members of the Obsoletus Complex (herein considered consisting of the species Culicoides obsoletus (Meigen), 1818, Culicoides scoticus Downes and Kettle, 1952, Culicoides chiopterus (Meigen), 1830 and Culicoides dewulfi Goetghebuer, 1936). The remaining 675 specimens represented six additional culicoid species (Table 2).

More Culicoides specimens (59.8\%) were collected inside than outside of the animal stables, equating a ratio of 1.6:1 (2072 indoors vs. 1393 outdoors). In total, the three cattle farms revealed almost five times as many sampled individuals $(n=2860)$ as the three horse farms $(n=574)$. Only 31 specimens were caught on the sheep farm (Table 2).

\section{Species composition}

The collections also show a higher number of midge species on cattle farms than on horse farms. On cattle farms, seven culicoid species could be found: the Obsoletus Complex (for this analysis regarded as one species), Culicoides pulicaris (Linnaeus), 1758, Culicoides punctatus (Meigen), 1804, Culicoides deltus Edwards, 1939, Culicoides riethi Kieffer, 1914, Culicoides pictipennis (Staeger), 1839 and Culicoides poperinghensis Goetghebuer, 1953. In comparison, only two species were collected on horse farms and the sheep farm: C. punctatus and Obsoletus Complex (Table 2).

Except for C. pictipennis, all collected culicoid species were found inside animal stables. Six species were sampled outdoors: Obsoletus Complex, C. deltus, C. pictipennis, C. pulicaris, C. punctatus and C. riethi (Table 2).

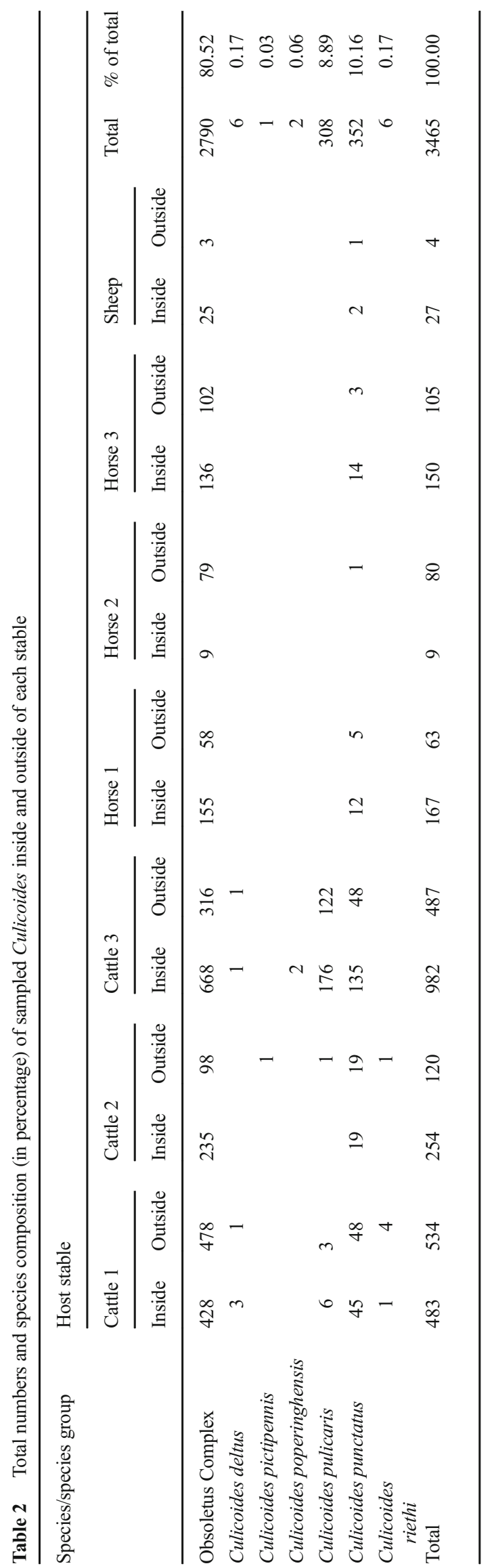




\section{First seasonal midge activity}

Midge activity could be observed as early as during the 12th calendar week inside the sheep stable and 1 week later inside all three cattle stables (Table 3).

Members of the Obsoletus Complex were the first midges caught at each collection site. At some sampling sites, where midge activity started during week 16 or later (inside all horse stables and all outdoors sites), species like $C$. punctatus and $C$. pulicaris were occasionally present among the first active culicoids in addition to the Obsoletus Complex (Table 3).

The minimum and maximum temperatures recorded during the entire time of sampling (including all study sites) were $-8.2{ }^{\circ} \mathrm{C}$ (weather station Airport Berlin-Brandenburg, 7 February 2015) and $26.9{ }^{\circ} \mathrm{C}$ (horse stable 2 indoors, 1 May 2015).

The threshold temperatures at the various sites were between 7.4 and $13.1{ }^{\circ} \mathrm{C}$ (Table 3) with a total mean threshold temperature of $10.5{ }^{\circ} \mathrm{C}$ for all collection sites (except sheep stable indoors due to missing data). The lowest temperatures within 7 days prior to the first sampled midge activity per site was often sub-zero, once even as low as $-1.1{ }^{\circ} \mathrm{C}$ (Table 3 ).

The average (minimum/maximum) temperatures of the day of the first measured midge activity per collection site varied from 8.3 to $16.2{ }^{\circ} \mathrm{C}$ (Table 3 ), resulting in a total mean daily temperature of $11.6^{\circ} \mathrm{C}$ for all trap locations.

\section{Onset of seasonal midge activity regarding species}

The first seasonally active species were midges of the Obsoletus Complex, followed by $C$. pulicaris and C. punctatus (Table 3) and, with some delay, by other culicoid species. This chronological order is also apparent in the species-specific threshold temperature pattern as illustrated in Table 4. Though no threshold temperature can be given for Obsoletus Complex (due to missing data), C. punctatus and $C$. pulicaris specimens started to show activity when the threshold temperatures rose up to $10.9^{\circ} \mathrm{C}$. Based on the early start of activity of Obsoletus Complex midges, their threshold temperature is therefore likely to be lower than $10.9^{\circ} \mathrm{C}$. Other culicoid species were collected when the threshold temperatures were much higher and reached $13.1,15.1$ and $16.9^{\circ} \mathrm{C}$ (Table 4).

Except for $C$. deltus and $C$. poperinghensis, below zero temperatures were recorded within 7 days prior to the species' first activity (Table 4).

When considering only sampling days with culicoid activity, the lowest minimum temperature was $-1.1^{\circ} \mathrm{C}$ (week 16 , horse stable 3 outdoors). The associated daily mean temperature was $8.3{ }^{\circ} \mathrm{C}$ when midges of the Obsoletus Complex were collected (Table 4).

As expected, the mean weekly temperatures recorded inside stables were higher than the corresponding temperatures outdoors. As illustrated in Fig. 1, they were highest inside the cattle stables (mean value for cattle stables 1-3), lower inside the horse stables (mean value for horse stables 1-3) and

Table 3 Time, species and temperature of the first seasonal midge activity at the various collection sites

\begin{tabular}{|c|c|c|c|c|c|}
\hline Farm & Site & $\begin{array}{l}\text { Week of first } \\
\text { activity }\end{array}$ & $\begin{array}{l}\text { Species sampled during first } \\
\text { midge activity }\end{array}$ & $\begin{array}{l}\text { Mean (lowest) temperature of } 7 \text { days prior to } \\
\text { first activity }\end{array}$ & $\begin{array}{l}\text { Mean } \\
(\min / \max ) \\
\text { temperature } \\
\text { on day of first } \\
\text { activity }\end{array}$ \\
\hline \multirow{2}{*}{$\begin{array}{c}\text { Horse } \\
1\end{array}$} & Inside & 16 & Obsoletus Complex & $11.8(7.4)$ & $9.0(6.1 / 10.8)$ \\
\hline & Outside & 17 & Obsoletus Complex & $10.1(-1.1)$ & $15.3(7.6 / 23.0)$ \\
\hline \multirow{2}{*}{$\begin{array}{c}\text { Horse } \\
2\end{array}$} & Inside & 17 & Obsoletus Complex & $11.2(4.8)$ & $10.6(7.6 / 14.2)$ \\
\hline & Outside & 17 & Obsoletus Complex, Culicoides punctatus & $9.4(-1.1)$ & $10.3(1.4 / 18.7)$ \\
\hline \multirow{2}{*}{$\begin{array}{c}\text { Horse } \\
3\end{array}$} & Inside & 16 & Obsoletus Complex, C. punctatus & $12.3(6.5)$ & $9.3(5.6 / 12.2)$ \\
\hline & Outside & 16 & Obsoletus Complex & $9.6(-0.8)$ & $8.3(-1.1 / 15.2)$ \\
\hline \multirow{2}{*}{$\begin{array}{c}\text { Cattle } \\
1\end{array}$} & Inside & 13 & Obsoletus Complex & $8.4(3.0)$ & $12.9(11.6 / 14.9)$ \\
\hline & Outside & 16 & Obsoletus Complex & $10.9(-0.3)$ & $10.4(4.2 / 13.9)$ \\
\hline \multirow{2}{*}{$\begin{array}{c}\text { Cattle } \\
2\end{array}$} & Inside & 13 & Obsoletus Complex & $7.4(2.8)$ & $12.0(11.1 / 13.6)$ \\
\hline & Outside & 16 & Obsoletus Complex & $10.9(-0.3)$ & $10.4(4.2 / 13.9)$ \\
\hline \multirow{2}{*}{$\begin{array}{c}\text { Cattle } \\
3\end{array}$} & Inside & 13 & Obsoletus Complex & $9.9(3.9)$ & $14.9(13.2 / 16.1)$ \\
\hline & Outside & 16 & $\begin{array}{l}\text { Obsoletus Complex, Culicoides pulicaris, } \\
\text { C. punctatus }\end{array}$ & $10.9(-0.3)$ & $10.4(4.2 / 13.9)$ \\
\hline \multirow[t]{2}{*}{ Sheep } & Inside & 12 & Obsoletus Complex & Not available & $16.2(14.1 / 20.4)$ \\
\hline & Outside & 19 & Obsoletus Complex, C. punctatus & $13.1(-0.2)$ & $12.4(5.1 / 17.5)$ \\
\hline
\end{tabular}


Table 4 Time and temperature of first midge activity per species

\begin{tabular}{lllll}
\hline Species & $\begin{array}{l}\text { Week } \\
\text { of first } \\
\text { activity }\end{array}$ & $\begin{array}{l}\text { Species- } \\
\text { specific } \\
\text { threshold } \\
\text { temperature } \\
\left({ }^{\circ} \mathrm{C}\right)\end{array}$ & $\begin{array}{l}\text { Minimum } \\
\text { temperature } \\
\text { of 7 days } \\
\text { prior to first } \\
\text { activity }\left({ }^{\circ} \mathrm{C}\right)\end{array}$ & $\begin{array}{l}\text { Lowest min } \\
\text { (mean/max })\end{array}$ \\
$\begin{array}{l}\text { during positive } \\
\text { sampling days } \\
\left({ }^{\circ} \mathrm{C}\right)\end{array}$ \\
\hline $\begin{array}{c}\text { Obsoletus } \\
\text { Complex }\end{array}$ & 12 & No data & No data & $-1.1(8.3 / 15.2)$ \\
$\begin{array}{c}\text { Culicoides } \\
\text { punctatus }\end{array}$ & 16 & 10.9 & -0.3 & $1.4(10.3 / 18.7)$ \\
$\begin{array}{c}\text { Culicoides } \\
\text { pulicaris }\end{array}$ & 16 & 10.9 & -0.3 & $2.6(12.5 / 20.7)$ \\
$\begin{array}{c}\text { Culicoides } \\
\text { deltus }\end{array}$ & 18 & 15.1 & 8.4 & $5.1(12.4 / 17.5)$ \\
$\begin{array}{c}\text { Culicoides } \\
\text { pictipennis }\end{array}$ & 19 & 13.1 & -0.2 & $5.1(12.4 / 17.5)$ \\
$\begin{array}{c}\text { Culicoides } \\
\text { riethi }\end{array}$ & 19 & 13.1 & -0.2 & $5.1(12.4 / 17.5)$ \\
$\begin{array}{c}\text { Culicoides } \\
\text { poperinghe- } \\
\text { nsis }\end{array}$ & 19 & 16.9 & 10.8 & $15.8(18.7 / 22.0)$ \\
\hline
\end{tabular}

${ }^{\text {a }}$ If the first activity started simultaneously at different sites, only the lowest temperatures were considered

almost identically low outside of the cattle and horse farms (mean value for farms 1-3) (Fig. 1).

\section{Endophily/exophily}

Activity of Culicoides started inside cattle stables in week 13, but the number of collected specimens remained on a low level until week 16, when midges began to show activity outside cattle stables as well. An explosive increase in midge numbers was measured in week 19 , the last week of sampling.
This increase was mostly caused by a much higher number of Obsoletus Complex midges, though in that week, $C$. punctatus and $C$. pulicaris were caught in relevant numbers, too. All three species were more abundant inside cattle stables throughout the entire sampling period which led to a higher total indoor number of Culicoides (Fig. 2).

On horse farms $1-3$, the first midge activity was measured in week 16 indoors and outdoors with very low specimen numbers. A temporary increase of both indoor and outdoor numbers took place in week 17 with the highest recorded number of specimens of the entire sampling period. Until week 18, more Culicoides were collected indoors than outdoors. Week 19 showed decreased numbers. Besides the Obsoletus Complex, which was by far the dominant species on horse farms $1-3$, only $C$. punctatus was sampled in low numbers. This species appeared mostly indoors until week 18 . Only in week 19 C. punctatus was caught in higher numbers outside the horse stables than indoors (Fig. 2).

\section{Discussion}

In the present study, we revealed a vector-free period inside and outside of stables which lasted until mid-march, 2015 (week 12). Some studies, usually conducted in countries with a milder climate (Romón et al. 2012), during milder winters (Losson et al. 2007; Mehlhorn et al. 2009a, b) or inside warm stables (Losson et al. 2007) were able to detect a constant culicoid activity throughout winter time, revealing a possible pathway of how Culicoides-borne arboviruses might survive the cold winter months in temperate regions. As ambient air temperatures during the time of sampling are considered to be
Fig. 1 Mean weekly temperatures measured inside and outside of the cattle and horse stables in calendar weeks $5-19$, 2015

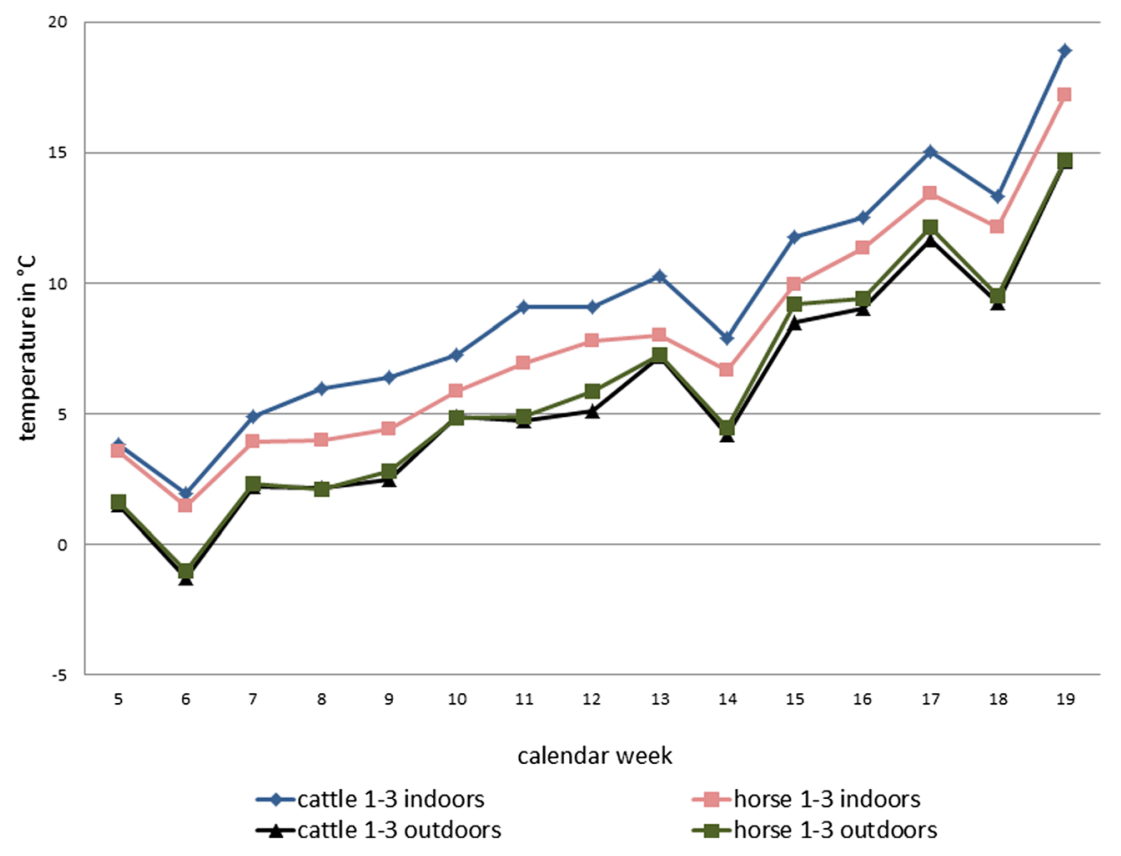




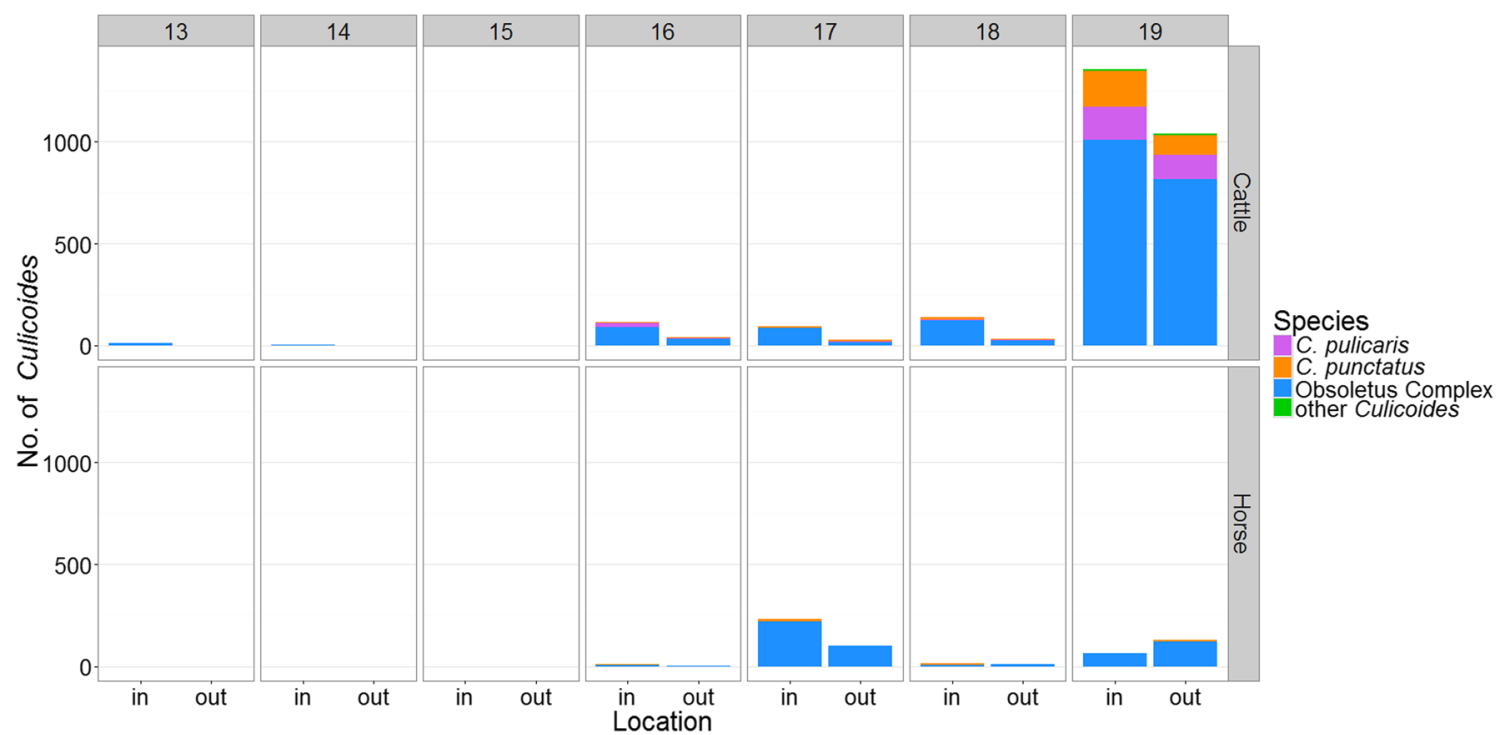

Fig. 2 Average number of caught midges in calendar weeks 13-19 inside and outside of cattle farms 1-3 (top) and of horse farms 1-3 (bottom)

the crucial factor to regulate midge activity (Lühken et al. 2015), a more detailed examination of the recorded temperatures is required when investigating the winter phenology of Culicoides.

\section{First seasonal midge activity}

Losson et al. (2007) showed that adult midges can remain active inside stables during winter due to a milder indoor climate. Therefore, it seemed likely that after the midge-free period in the present study, culicoid activity could be found inside stables first. Our results partly confirm the hypotheses of an early indoor activity, with midges being sampled inside the sheep and all three cattle stables. But the simultaneous start of midge activity inside the horse stables and at all outdoor sites seems to question this explanation and implies that other factors might have delayed the start of culicoid activity inside the (warmer) horse stables. We assume, that most midges at horse farms develop outdoors and, once temperatures are high enough, emerge and become active outside of the stables. Some of the active culicoids might then also enter the horse stables, leading to an almost equal number of specimens collected indoors and outdoors in week 16 in the present study (Fig. 2).

A comparison of indoor and outdoor sampling sites revealed that the mean weekly threshold temperatures were slightly above $10{ }^{\circ} \mathrm{C}$, which is in accordance to the temperatures determined under laboratory conditions (Lühken et al. 2015).

Should our theory be correct though, that midges did not develop inside horse stables in bigger numbers, the corresponding threshold temperature for inside horse stables should not be considered. Instead, the correlated outdoor temperature of $9.7{ }^{\circ} \mathrm{C}$ (outside horse stables $1-3$ ) seems to be the true threshold temperature for midge activity on the horse farms in the present investigation. As the lowest threshold temperature of all sampling sites was $7.4{ }^{\circ} \mathrm{C}$ (inside cattle stable 2), this field-measured temperature seems to provide sufficient warmth to initiate midge activity.

Quite often, minus temperatures were recorded within 7 days before the first midge activity took place (Table 3). Even during the day of the first measured midge activity, temperatures were as low as $-1.1{ }^{\circ} \mathrm{C}$ (Table 3 ) which proves that even below zero degrees do not prevent midge development or adult culicoid activity, as long as the freezing is only short-termed.

\section{Species composition}

The culicoid species composition found in the present study (including all sampling sites) equates the species composition stated for most of Germany with the Obsoletus Complex being represented by $70 \%$ to $>90 \%$, the Pulicaris Complex by up to $20 \%$ of the present Culicoides and only relatively few specimens belonging to other culicoid species (Hörbrand and Geier 2009; Mehlhorn et al. 2009a, b). In this context, it was irrespective of the trapping sites being located indoors or outdoors. Therefore, the overall species composition seems not to be influenced by possible (temporary) endophilic/exophilic tendencies of some culicoid species in the present study.

Species composition and the number of collected midges differed strongly between livestock animals though, with cattle farms representing the most culicoid species and highest specimen numbers compared with all horse farms and the sheep farm (Table 2).

The extremely low number of sampled Culicoides on the sheep farm might be explained by the isolated and windy location of the farm. The differing species composition and 
midge numbers between cattle and horse farms might be caused by variant husbandry practises. Better clean outs of horse stables for example, might lead to a lack of microhabitats, which might be present only in cattle stables, e.g. dried cattle dung adherent to walls as proposed by Zimmer et al. (2010). Also, the better quality of the moist cattle dung as a potential breeding substrate as compared with the drier horse and sheep droppings might add to the higher number of Obsoletus Complex specimens being caught on cattle farms as described by Thompson et al. (2013). Undetected breeding sites in the surroundings of cattle farms cannot be ruled out as well. As all study farms and their neighbourhoods had been inspected carefully before the start of the study and considered as "comparable with each other", we consider this explanation as relatively unlikely, though. Based on our own experience, differences in the species composition between the two sampled regions do not exist as well.

Blood host preferences could also have had an impact on the distribution of some culicoid species between farms. Even though Obsoletus Complex midges are known to be the generalists in the genus Culicoides (Lassen et al. 2012), it cannot be ruled out that other culicoid species which are represented only by a few individuals and which have not sufficiently been analysed in regards to their blood feeding preferences, might just not be present on the horse or sheep farms because these livestock animals do not belong to their preferred range of blood hosts.

\section{Onset of seasonal activity regarding species}

In the present study, the species-specific threshold temperatures, triggering midge activity, differ widely (Table 4). While C. punctatus and C. pulicaris started to show activity after their threshold temperatures reached nearly $11^{\circ} \mathrm{C}$, the threshold temperatures for $C$. deltus, C. pictipennis, C. riethi and C. poperinghensis seem to be higher. Therefore, it may be possible, that these species may have appeared on horse farms, too, once temperatures have reached the species' threshold temperatures after the end of the sampling period. As only a low number of farms were sampled and only few midge specimens per species were collected, the species-specific threshold temperatures should be interpreted with care and provide only a first baseline dataset for future studies.Except for $C$. poperinghensis and $C$. deltus, all collected species were able to resist short-termed minus degrees, when minimum temperatures (within 7 days prior to their first activity) went down to below zero (Table 4).

\section{Endophily/exophily}

In our investigation, the total number of sampled Culicoides was higher indoors than outdoors with a ratio of 1.6:1, which may be attributed to the higher indoor temperatures. Previous studies proved a strong exophily for culicoid midges (Baldet et al. 2008; Baylis et al. 2010; Meiswinkel et al. 2008) and also described varying underlying conditions in their investigations, e.g. livestock movements between indoor and outdoor resting places (Meiswinkel et al. 2008) or higher outdoor temperatures caused by different sampling seasons (Baylis et al. 2010; Meiswinkel et al. 2008). Baldet et al. (2008) assumed that Culicoides are neither purely endophilic nor exophilic but may behave according to outdoor temperatures. The results of the present investigation show a noticeable preference for indoor locations at least during the coldest time of the year (Fig. 2). Nevertheless, the fact that more Obsoletus Complex midges were caught outside of horse stables in week 19 suggest, that their habitat preferences are not rigidly predetermined, but a reaction to environmental factors, conceivably temperature, as proposed by Baldet et al. (2008). According to our findings, the adaptation to endo-/exophilic behaviour does not only account for Obsoletus Complex midges, but also for $C$. punctatus. Though $C$. punctatus was only sampled in small numbers on horse farms, it was caught in higher numbers inside than outside horse stables except for week 19 when more specimens were collected outdoors (Fig. 2). The total numbers of collected C. punctatus, but also of $C$. pulicaris, reveal a marginal endophilic tendency of these species at least during the cold winter months. This is contrary to previous results published by Baldet et al. (2008) and Meiswinkel et al. (2008), who illustrated a strong exophilic behaviour for both species.

Other species like $C$. riethi and $C$. deltus were only represented by six individuals each. Due to the low number of specimens, it is impossible to evaluate, if the observed endophilic tendency for $C$. deltus and the exophilic tendency for $C$. riethi represent an actual pattern of behaviour.

Regarding endophily and exophily of the various biting midge species, it needs to be taken into account that only three horse farms, three cattle farms and one sheep farm were investigated. Thus, the data should be considered preliminary. They may illustrate the complexity of the midges' behaviour and phenology and demonstrate the necessity for more research.

\section{Conclusion}

We found a vector-free period in our investigation lasting until mid-March, 2015. We showed that the first seasonal biting midge activity was initiated by a threshold temperature of at least $7.4{ }^{\circ} \mathrm{C}$ and that even below zero temperatures did not prevent midge development or adult midge activity, as long as the freezing was only short-termed.

The type of livestock animals seemed to influence the starting time of midge activity, the species composition and the numbers of midges collected. This may be attributed to 
differences in ambient temperature and, most likely, also to husbandry practises. Midges of the Obsoletus Complex were the first to become active.

Species composition hardly differs between indoor and outdoor trapping sites during early spring as most species were present both indoors and outdoors. This suggests that they are not strictly endophilic or exophilic, but that behaviour is influenced by environmental factors.

Acknowledgements We would like to express our deepest gratitude to all participating farmers for their full support and cooperation and for providing access to their livestock buildings. This investigation was funded by the doctoral commission of the Leibniz Centre for Agricultural Landscape Research, Germany.

Conflict of interest The authors declare that there is no conflict of interest.

Open Access This article is distributed under the terms of the Creative Commons Attribution 4.0 International License (http:// creativecommons.org/licenses/by/4.0/), which permits unrestricted use, distribution, and reproduction in any medium, provided you give appropriate credit to the original author(s) and the source, provide a link to the Creative Commons license, and indicate if changes were made.

\section{References}

Baldet T, Delécolle J-C, Cêtre-Sossah C, Mathieu B, Meiswinkel R, Gerbier G (2008) Indoor activity of Culicoides associated with livestock in the bluetongue virus (BTV) affected region of northern France during autumn 2006. Prev Vet Med 87(1-2):84-97. doi:10.1016/j.prevetmed.2008.06.014

Baylis M, Parkin H, Kreppel K, Carpenter S, Mellor PS, Mcintyre KM (2010) Evaluation of housing as a means to protect cattle from Culicoides biting midges, the vectors of bluetongue virus. Med Vet Entomol 24(1):38-45. doi:10.1111/j.1365-2915.2009.00842.x

Conraths FJ, Kämer D, Teske K, Hoffmann B, Mettenleiter TC, Beer M (2013) Reemerging Schmallenberg virus infections, Germany, 2012. Emerg Infect Dis 19(3):513-514. doi:10.3201 /eid1903.121324

De Regge N, Deblauwe I, De Deken R, Vantieghem P, Madder M, Geysen D, Smeets F, Losson B, van den Berg T, Cay AB (2012) Detection of Schmallenberg virus in different Culicoides spp. by real-time RT-PCR. Transbound Emerg Dis 59(6):471-475. doi:10.1111/tbed.12000

Delécolle J-C (1985) Nouvelle contribution à l'étude systématique et iconographique des espèces du genre Culicoides (Diptera: Ceratopogonidae) du Nord-Est de la France. Ph.D. thesis, Université Louis Pasteur de Strasbourg

Doceul V, Lara E, Sailleau C, Belbis G, Richardson J, Bréard E, Viarouge C, Dominguez M, Hendrikx P, Calavas D, Desprat A, Languille J, Comtet L, Pourquier P, Eléouët J-F, Delmas B, Marianneau P, Vitour D, Zientara S (2013) Epidemiology, molecular virology and diagnostics of Schmallenberg virus, an emerging Orthobunyavirus in Europe. Vet Res 44:31. doi:10.1186/1297-9716-44-31

EFSA (2012) "Schmallenberg" virus: analysis of the epidemiological data and assessment of impact. EFSA J 10(6):2768. doi:10.2903/j. efsa.2012.2768
EFSA (2014) Schmallenberg virus: state of art. EFSA J 12(5):3681. doi:10.2903/j.efsa.2014.3681

Goffredo M, Monaco F, Capelli G, Quaglia M, Federici V, Catalani M, Montarsi F, Polci A, Pinoni C, Calistri P, Savini G (2013) Schmallenberg virus in Italy: a retrospective survey in Culicoides stored during the bluetongue Italian surveillance program. Prev Vet Med 111(3-4):230-236. doi:10.1016/j.prevetmed.2013.05.014

Hoffmann B, Saßerath M, Thalheim S, Bunzenthal C, Strebelow G, Beer M (2008) Bluetongue virus serotype 8 reemergence in Germany, 2007 and 2008. Emerg Infect Dis 14(9):1421-1423. doi:10.3201 /eid1409.080417

Hoffmann B, Bauer B, Bauer C, Bätza H-J, Beer M, Clausen P-H, Geier M, Gethmann JM, Kiel E, Liebisch G, Liebisch A, Mehlhorn H, Schaub GA, Werner D, Conraths FJ (2009) Monitoring of putative vectors of bluetongue virus serotype 8, Germany. Emerg Infect Dis 15(9):1481-1484. doi:10.3201/eid1509.090562

Hörbrand T, Geier M (2009) Monitoring of Culicoides at nine locations in southern Germany (2007-2008). Parasitol Res 105(2):387-392. doi:10.1007/s00436-009-1415-Z

Larska M, Lechowski L, Grochowska M, Zmudzinski JF (2013) Detection of the Schmallenberg virus in nulliparous Culicoides obsoletus/scoticus complex and C. punctatus - the possibility of transovarial virus transmission in the midge population and of a new vector. Vet Microbiol 166(3-4):467-473. doi:10.1016/j. vetmic.2013.07.015

Lassen SB, Nielsen SA, Kristensen M (2012) Identity and diversity of blood meal hosts of biting midges (Diptera: Ceratopogonidae: Culicoides Latreille) in Denmark. Parasit Vectors 5:143. doi:10.1186/1756-3305-5-143

Lehmann K, Werner D, Hoffmann B, Kampen H (2012) PCR identification of culicoid biting midges (Diptera: Ceratopogonidae) of the Obsoletus complex including putative vectors of bluetongue and Schmallenberg viruses. Parasit Vectors 5:213

Losson B, Mignon B, Paternostre J, Madder M, De Deken R, De Deken G, Deblauwe I, Fassotte C, Cors R, Defrance T, Delécolle J-C, Baldet T, Haubruge E, Frédéric F, Bortels J, Simonon G (2007) Biting midges overwintering in Belgium. Vet Rec 160(13):451452. doi:10.1136/vr.160.13.451-b

Lühken R, Steinke S, Hoppe N, Kiel E (2015) Effects of temperature and photoperiod on the development of overwintering immature Culicoides chiopterus and C. dewulfi. Vet Parasitol 214(1-2):195199. doi:10.1016/j.vetpar.2015.10.001

Mathieu B, Cêtre-Sossah C, Garros C, Chavernac D, Balenghien T, Carpenter S, Setier-Rio M-L, Vignes-Lebbe R, Ung V, Candolfi E, Delécolle J-C (2012) Development and validation of IIKC: an interactive identification key for Culicoides (Diptera: Ceratopogonidae) females from the western Palaearctic region. Parasit Vectors 5:137. doi:10.1186/1756-3305-5-137

Mehlhorn H, Walldorf V, Klimpel S, Jahn B, Jaeger F, Eschweiler J, Hoffmann B, Beer M (2007) First occurrence of Culicoides obsoletus-transmitted bluetongue virus epidemic in Central Europe. Parasitol Res 101(1):219-228. doi:10.1007/s00436-0070519-6

Mehlhorn H, Walldorf V, Klimpel S, Schaub G, Kiel E, Focke R, Liebisch G, Liebisch A, Werner D, Bauer C, Clausen H, Bauer B, Geier M, Hörbrand T, Bätza H-J, Conraths FJ, Hoffmann B, Beer M (2009a) Bluetongue disease in Germany (2007-2008): monitoring of entomological aspects. Parasitol Res 105(2):313-319. doi:10.1007 /s00436-009-1416-y

Mehlhorn H, Walldorf V, Klimpel S, Schmahl G, Al-Quraishy S, Walldorf U, Mehlhorn B, Bätza H-J (2009b) Entomological survey on vectors of bluetongue virus in Northrhine-Westfalia (Germany) during 2007 and 2008. Parasitol Res 105(2):321-329. doi:10.1007 /s00436-009-1413-1

Meiswinkel R, Goffredo M, Dijkstra EG, van der Ven IJ, Baldet T, Elbers A (2008) Endophily in Culicoides associated with BTV-infected 
cattle in the province of Limburg, South-Eastern Netherlands, 2006. Prev Vet Med 87(1-2):182-195. doi:10.1016/j. prevetmed.2008.06.008

Mellor PS, Boorman J, Baylis M (2000) Culicoides biting midges: their role as arbovirus vectors. Annu Rev Entomol 45:307-340. doi:10.1146/annurev.ento.45.1.307

Napp S, Gubbins S, Calistri P, Allepuz A, Alba A, García-Bocanegra I, Giovannini A, Casal J (2011) Quantitative assessment of the probability of bluetongue virus overwintering by horizontal transmission: application to Germany. Vet Res 42:4. doi:10.1186/12979716-42-4

Rasmussen LD, Kristensen B, Kirkeby C, Rasmussen TB, Belsham GJ, Bødker R, Bøtner A (2012) Culicoids as vectors of Schmallenberg virus. Emerg Infect Dis 18(7):1204-1206. doi:10.3201 /eid1807.120385

Rawlings P, Mellor PS (1994) African horse sickness and the overwintering of Culicoides spp. in the Iberian peninsula. Rev Sci Tech 13(3):753-761

Romón P, Higuera M, Delécolle J-C, Baldet T, Aduriz G, Goldarazena A (2012) Phenology and attraction of potential Culicoides vectors of bluetongue virus in Basque Country (northern Spain). Vet Parasitol 186(3-4):415-424. doi:10.1016/j.vetpar.2011.11.023

Rowley WA (1967) Observations on larval habitats and the winter bionomics of some common species of Culicoides (Diptera: Ceratopogonidae) in the Central Columbia basin. Mosquito News 27(4):499-505

Tarlinton R, Daly J, Dunham S, Kydd J (2012) The challenge of Schmallenberg virus emergence in Europe. Vet J 194(1):10-18. doi:10.1016/j.tvj1.2012.08.017

Thompson GM, Jess S, Murchie AK (2013) Differential emergence of Culicoides (Diptera: Ceratopogonidae) from on-farm breeding substrates in northern Ireland. Parasitology 140(6):699-708. doi:10.1017/S0031182012002016

Wernike K, Kohn M, Conraths FJ, Werner D, Kameke D, Hechinger S, Kampen H, Beer M (2013) Transmission of Schmallenberg virus during winter, Germany. Emerg Infect Dis 19(10):1701-1703. doi:10.3201/eid1910.130622

Zimmer J-Y, Saegerman C, Losson B, Haubruge E (2010) Breeding sites of bluetongue virus vectors, Belgium. Emerg Infect Dis 16(3):575576. doi:10.3201/eid1603.091311 